\title{
Kadmiyum Verilen Dişi Sıçanlarda Üreme Sistemi Üzerine Melatonin ve Selenyumun Etkisi
}

\author{
Effect of Melatonin and Selenium on Reproductive System of \\ Cadmium Given Female Rats
}

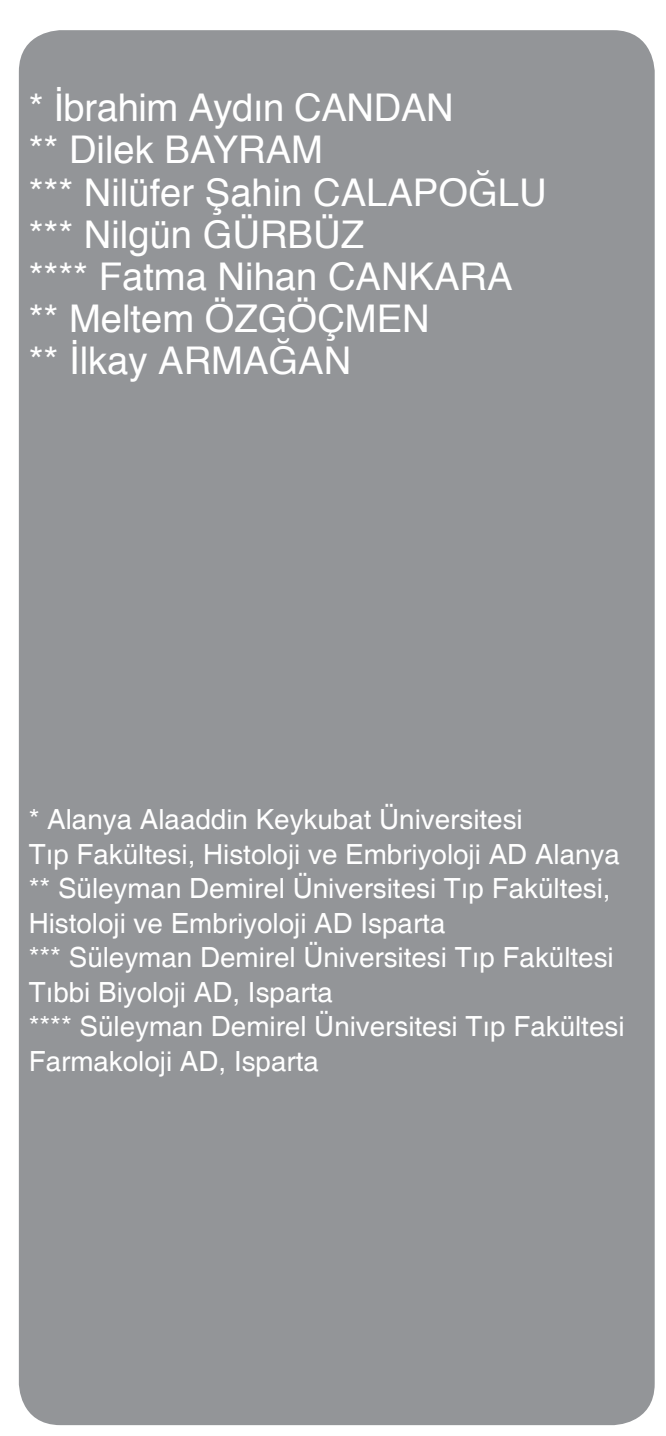

Yazıșma Adresi:

Yrd. Doç. Dr. Dilek BAYRAM

Süleyman Demirel Üniversitesi Tıp Fakültesi,

Histoloji ve Embriyoloji AD Isparta

Tel: 05052313665

e-mail: dilekbayram@sdu.edu.tr

\section{Öz}

Amaç: Fosfatlı gübrelerde, deterjanlarda ve rafine petrol türevlerinde bulunan kadmiyum, 1817 yılında keşfedilmiş toksik ağır bir metaldir ve sigaranın majör bileşenlerinden biridir. Selenyum serbest radikallerin üretimini azaltmak ve önlemek için gerekli olan, doymamış yağ asitlerinden türeyen ve peroksitleri yok ettiği düşünülen bir elementtir. Melatonin, pineal bezin majör hormonudur. Organizma, serbest radikallerin neden olduğu hücre hasarını önlemek için antioksidan savunma sistemi geliştirir. Bu çalışmada, kadmiyumun vücutta dokularda birikerek oluşturduğu toksisite üzerine Selenyum (Se) ve Melatoninin etkisinin belirlenmesi amaçlandı. Gereç-Yöntem: Deney grupları; her grupta 8 dişi sıçan olmak üzere, kontrol (Grup I), Kadmiyum (Grup II), Melatonin (Grup III), Selenyum (Grup IV), Kadmiyum+Melatonin (Grup V), Kadmiyum+Selenyum (Grup $\mathrm{VI}$ ), Melatonin+Selenyum (Grup VII) ve Kadmiyum+Melatonin+Selenyum (Grup VIII) şeklinde düzenlendi. Kadmiyum (2 mg/kg/gün; gavajla), Melatonin ( $3 \mathrm{mg} / \mathrm{kg} / \mathrm{gün}$; intraperitoneal) 30 gün boyunca günde bir kez, selenyum ise 5'er gün arayla 30 günde 6 kez uygulandı. Deney sonunda over, tuba uterina ve uterus dokuları alınarak, bir kısmı histokimyasal ve immünohistokimyasal değerlendirme için \%10'luk nötral formaldehit içerisine, diğer kısmı ise biyokimyasal çalışma için fosfat tamponu içerisine ve kan örnekleri apopitotik hücre ve DNA fragmantasyonu tayini için EDTA'lı tüplere alındı. Bulgular, Sonuç ve Tartışma: Çalışmamızın sonunda kadmiyum verilmesine bağlı olarak over, tuba uterina ve uterus dokularında MDA düzeyleri kontrol grubuna göre artış gözlendi. GSPx ve CAT aktivite değerlerinde de artış saptandı. Grup III, VII ve VIII' de benzer parametreler gözlendi. Grup V ve Vl' da ise antioksidanların etkisi ile lipid peroksidasyon engellenerek MDA, GSPx ve CAT düzeylerinin kadmiyuma göre düştüğü tespit edildi. DNA ladder kit ile yapılan analizler sonucunda sadece kadmiyum verilen grupta DNA fragmantasyonu ve buna bağlı olarak apopitotik hücre artışı gözlendi. Histolojik ve immünohistokimyasal bulgularımızda biyokimyasal analizler ve DNA ladder değerlerine paralel sonuçlar elde edildi. Kadmiyum grubunun bütün dokularında hasar (overlerin foliküllerinde dejenerasyon, hemorajik alanlar, mononükleer hücre infiltrasyonu ve bağ dokusu artışı; tuba uterina'nın epitelinde dejenerasyon ve tübüllerinde dejenerasyon; uterusun epitelinde dejenerasyon, endometriyum tabakasında dilate alanlar ve endometriyal bezlerde dejenerasyon), E-kaderin, NCAM sentezinde artış ve dokularda yüksek MT-3 birikimi gözlendi. Grup VI ve VIII' de anlamlı histopatolojik düzelmeler gözlemlendi, ancak grup V'te herhangi bir düzelme tespit edilemedi. Kadmiyumun dişi genital sistem organlarında hasar meydana getirdiğini, selenyumun dokuları bu hasardan korurken Melatoninin herhangi bir koruyucu ya da düzeltici etkisi olmadığı gözlendi. Melatoninin koruyucu bir etki gösterememesinin sebebini dişi sıçanların hormonal 
değişimlerine ve Melatoninin uzun süreli kullanımına bağlı olabileceği düşünüldü. Çalışmamızın kadmiyum tedavisine ya da korumasına katkı sağlamasını ve yeni tedavi yollarına basamak teşkil etmesini umuyoruz.

Anahtar Kelimeler: Kadmiyum, Selenyum, Melatonin, Metallotiyonin, Adezyon Molekülleri

\section{Abstract}

Aim: Cadmium which is discovered in 1817 is a toxic heavy metal and found in phosphate fertilizers, detergents and refined petroleum and it's one of the major components of cigarette smoking. Selenium is an element, derived from unsaturated fatty acids, thought to degrade peroxides and needed to reduce - prevent the production of free radicals. Melatonin is the major hormone of the pineal gland and it is develops an antioxidant defense system to prevent cell damage caused by free radicals in organism. In our study, it was aimed to determine whether Selenium and Melatonin show antioxidant properties on the toxicity that cadmium accumulates on tissues in the body. Material Method: Experimental groups; Control (Group I), Cadmium (Cd) (Group II), Melatonin (Group III), Selenium (Group IV), Cadmium+Melatonin (Group V), Cadmium+Selenium (Group VI), Melatonin+Selenium (Group VII) and Cadmium + Melatonin + Selenium (Group VIII) were arranged to be 8 female rats in each group. Cadmium (2 mg / kg / day with gavage), Melatonin ( $3 \mathrm{mg} / \mathrm{kg} / \mathrm{day}$, intraperitoneal) 30 days were applied once a day and seleneium was applied 6 times in 30 days, 5 days a day. At the end of the experiment, over, tuba uterine and uterus tissues were taken. Some of the receiving tissues were in $10 \%$ neutral formaldehyde for histochemical and immunohistochemical evaluation and the other were in phosphate buffer for biochemical study and bloods were taken into the EDTA tube for apoptotic cell and DNA fragmentation assay. Results and Discussion: At the end of our study, MDA levels were increased in the over, tubal uterine and uterine tissues according to the cadmium administration group and also increase in GSPx and CAT activity values was detected, similar parameters were also observed in group III, group VII, group VIII. But in group V and group $\mathrm{VI}$, were found to inhibit lipid peroxidation of antioxidants and decrease MDA, GSPx and CAT levels compared to cadmium. As a result of the analysis with DNA ladder kit, DNA fragmentation and consequently apoptotic cells number were observed only in the cadmium-administered group. Histological and immunohistochemical findings gave parallel results to biochemical analyzes and DNA ladder values. in all the tissues of the cadmium group were observed; High MT-3 accumulation, damage (degeneration of ovarian follicles, haemorrhagic areas, mononuclear cell infiltration and increased connective tissue; degeneration in tuba uterina epithelium and degeneration in tubules; degeneration in the uterine epithelium, dilate fields in the endometrium layer and degeneration in the endometrial glands) and increase in E-cadherin, NCAM synthesis. When significant improvements were observed in group $\mathrm{VI}$ and group VIII, there were no improvement in the group V. We have seen that cadmium brings damage to the female genital system organs and while selenium has protective effect for tissues from this damage, Melatonin has not a protective or corrective effect but we think, the cause of this event because of to hormonal changes of female rats and the long-term use of Melatonin. At last, we hope that our work will contribute to cadmium treatment or protection and will provide a stepping stone to new ways of treatment.

Keywords: Cadmium, Selenium, Melatonin, Methallothionein, Adhesion molecules

\section{Giriş}

Çevre kirliliğine sebep olan kimyasal kirleticiler arasında; çevre koşullarına dayanıklı olmaları ve biyolojik sistemlere yönelik genelde zararlı etki göstermeleri nedeniyle ağır metaller ayrı bir önem taşımaktadır. Bu metaller kolaylıkla besin zincirine girerek canlılarda artan yoğunluklarda birikerek toksik etki oluşturmaktadır.(1) Endüstriyel ve çevresel kirletici olarak önemi son yıllarda daha da belirginleșen, çevredeki en toksik ağır metallerden biri kadmiyumdur. (2)

Kadmiyum (Cd) non korozif özelliği sebebiyle kaplama ve galvanizasyon ile uçak sanayinde, nükleer santrallerde nötron absorplayıcı olarak, insektisit formülasyonlarında, plastik yapımında stabilizatör olarak, boya ve nikel kadmiyumlu pil sanayisinde, fosfatlı gübrelerde, deterjanlarda, rafine petrol türevlerinde ve sigarada yaygın kullanımından dolayı büyük bir kadmiyum kirliliği ortaya çıkmaktadır (3-5). Cd birçok somatik (CEM-C12 insan $\mathrm{T}$ lenfositlerinde, CL-3 insan karsinoma hücrelerinde ve insan HeLa hücrelerinde, fare karaciğerinde, sıçan akciğer hücrelerinde ve fibroblast hücrelerinde, domuz böbrek hücrelerinde) ve üreme (Sıçan testisinde) hücrelerinde in vitro ve in vivo olarak apopitoza neden olmuştur (6).

Vücuttaki farklı organlara kan yoluyla hızlı bir şekilde giren kadmiyum yüksek derecede bağlanma afinitesi gösteren metallotiyonin sayesinde çeşitli organ ve dokularda birikir (7). Kadmiyum toksisitesine duyarlı ovaryum ve testis gibi üreme organlarıyla embriyolar üzerinde kadmiyum oldukça 
ağır hasara neden olmaktadır (8). Uluslararası Kanser Araştırma Merkezi tarafından bir insan karsinogeni olarak da adlandırılan kadmiyum anormal gen ekspresyonu, DNA onarıcı enzimleri inhibe ederek DNA onarım sürecinin inhibisyonu, oksidatif stresin indüklenmesi ve E-cadherin fonksiyon bozukluğu yaparak kansere neden olabilmektedir (7). Dişi sıçanlar üzerinde yapılan deneysel çalışmalarda, ovulasyona yakın zamanda kadmiyum verilmesinin ovulasyonu durdurduğu, granüloza hücre morfolojisi ve steroid biyosentezi üzerine direkt etki ederek progesteron üretimini azalttığı bildirilmiştir (9-11).

Kaderinler, hücre yapışmasında ve farklılaşmasında rolleri olan ve birçok dokuda şekillenebilen hücre adezyon reseptörleridirler (12). Kaderinler, tutturucu bağlantı (zonula adherens), sıkı bağlantı (zonula okludens) bölgeleri ve desmozomlarda meydana gelen homotipik bağlantıları düzenlerler (13).

Sinir hücre adezyon molekülü (NCAM) ise kollajen, heparin, heparan sülfat ve kondroitin sülfat proteoglikanları ile etkileşime girer ve embriyogenez sırasında normal doku mimarisinin gelişimi ve hücre büyümesi sırasında izlenen kontakt inhibisyona katılır $(13,14)$.

Selenyum (Se), DNA sentezinde, oksidatif strese karşı savunmada rol oynayan ve protein onarımında gerekli olan önemli bir enzim olan Tioredoksin redüktaz'ın bir bileşenidir (15). Antioksidan bir enzim olan glutatyon peroksidaz (GSH-Px) aktivitesinin sağlanması için gerekli olan çok önemli bir kofaktördür (16). Bu elementin siroz, kanser, diyabet ve kalp damar rahatsızlıklarını önlemek veya tedavi etmek için uygun değer günlük alınımın ne kadar olacağı belirlenmiştir (17).

Pineal bezden salgılanan ana ürün olan Melatoninin (Mel); sirkadiyen ve mevsimsel ritim, retinal fizyoloji, immün ve üremefonksiyonlarıüzerindeetkilerivardır. Oksidatif stresten sorumlu olan serbest oksijen radikallerinin (ROS) varlığında Melatoninin (N-metoksitriptamin) pirol halkasından $\mathrm{N}$-asetil-
$\mathrm{N}$-formil-5- metoksikinurenamin oluşumuyla serbest radikalleri tuttuğu, lipit peroksidasyonunu peroksil radikalini yakalayarak engellediği, superoksit dismutaz (SOD), GSHPx, Glutatyon redüktaz, Glukoz-6-Fosfat Dehidrogenaz enzimlerinin gen ekspresyonları ya da aktivitelerini artırmakla oksidatif stresi baskıladığı bilinmektedir $(18,19)$. $\mathrm{Bu}$ çalışmadaki amaç, kadmiyumun dişi üreme sistemi üzerinde meydana getirdiği toksik etkilere karşı antioksidan ajanlar olan selenyum ve Melatoninin koruyucu etkilerinin olup olmadığını araştırmaktır.

\section{Gereç ve Yöntem}

$\mathrm{Bu}$ çalışmanın deneysel kısmı Süleyman Demirel Üniversitesi Deney Hayvanları Araştırma Merkezi, Tıp Fakültesi Tıbbi Biyoloji Anabilim Dalı ve Histoloji ve Embriyoloji Anabilim Dalı Araştırma Laboratuarlarında etik kurallara uygun olarak gerçekleştirildi (HADYEK Onay no: 21438139-366).

Çalışmada ağırıkları 180-230 gr arasında değiş̧en, toplam 64 adet Wistar Albino cinsi Dişi sıçan (rat) kullanıldı. Deney süresince sıçanların su ve yeme (Yem Kurumu Standart Fare Yemi) sınırsız erişimine (ad libitum) izin verildi.

\section{Deney Planı}

Çalıșmada, her grupta 8 diși sıçan $(n=8)$ olmak üzere 7 ayrı deney grubu ve bir kontrol grubu oluşturuldu ve toplam 64 sıçan ( $\mathrm{n=64)}$ kullanıldı. Gruplar: Grup I (Kontrol), Grup II (Cd, Grup III (Mel), Grup IV (Se), Grup V (Cd + Mel), Grup VI (Cd $+\mathrm{Se})$, Grup VII (Mel + Se), Grup VIII $(\mathrm{Cd}+\mathrm{Mel}+\mathrm{Se})$.

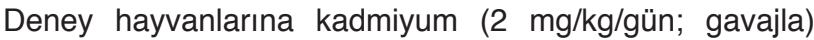
(Kadmiyum Klorür, Alfaeaser Cat: 13677 Russia) (20), Melatonin (3 mg/kg/gün; intraperitoneal) (Sigma Cat: M5250 China) (21) 30 gün gece günde birkez, selenyum (Alfaeaser Cat: 12613 USA) (20) ise 5'er gün arayla 30 günde $6 \mathrm{kez}$ uygulandı. Melatoninin gece aktif olmasından dolayı bütün ajanlarımız ratlara gece verildi. (Tablo)

Tablo: Deney grupları, verilen kimyasalların dozları ve günleri

\begin{tabular}{|c|c|c|c|c|}
\hline $\begin{array}{c}\text { Deney } \\
\text { Grupları }\end{array}$ & $\begin{array}{c}\text { Hayvan } \\
\text { Sayısı }\end{array}$ & Verilen Kimyasal Türü & Verilen Doz Miktarı & Süre (Gün) \\
\hline I & 8 & Serum fizyolojik & $2 \mathrm{mg} / \mathrm{ml}$ & 30 \\
\hline II & 8 & Kadmiyum & $2 \mathrm{mg} / \mathrm{ml}$ & 30 \\
\hline III & 8 & Melatonin & $3 \mathrm{mg} / \mathrm{ml}$ & 30 \\
\hline VI & 8 & Selenyum & $1 \mathrm{mg} / \mathrm{ml}$ & 6 \\
\hline V & 8 & Kadmiyum+melatonin & $2 \mathrm{mg} / \mathrm{ml}+3 \mathrm{mg} / \mathrm{ml}$ & 30,30 \\
\hline VI & 8 & Kadmiyum+selenyum & $2 \mathrm{mg} / \mathrm{ml}+1 \mathrm{mg} / \mathrm{ml}$ & 30,6 \\
\hline VII & 8 & Melatonin+selenyum & $3 \mathrm{mg} / \mathrm{ml}+1 \mathrm{mg} / \mathrm{ml}$ & 30,6 \\
\hline VIII & 8 & Kadmiyum+melatonin+5elenyum & $2 \mathrm{mg} / \mathrm{ml}+3 \mathrm{mg} / \mathrm{ml}+1 \mathrm{mg} / \mathrm{ml}$ & $30,30,6$ \\
\hline
\end{tabular}


30 günlük deney sonunda sıçanlara $90 \mathrm{mg} / \mathrm{kg}$ ketamin- $\mathrm{HCl}$ (Alfamin, Alfasan IBV) ve $10 \mathrm{mg} / \mathrm{kg}$ ksilazin hidroklorür i.p. anestezi uygulanarak ve sakrifiye edildi. Ratların dişi genital sistem organları (Over, tuba uterina ve uterus) alındı. Alınan dokular histolojik ve immünohistokimyasal çalışmalar için \%10'luk nötral formaldehit içerisine, biyokimyasal çalışmalar için fosfat tamponu içerisine ve sıçanların kanları da apopitotik hücre ve DNA fragmantasyonu tayini için EDTA’ı tüplere alındı.

\section{Biyokimyasal Analizler}

\section{MDA (Malondialdehit) Ölçümü}

MDA (Malondialdehit) ölçümü Draper ve Hadley'in metoduna göre yapıldı (22). Yağ asidi peroksidasyonunun son ürünü olan malondialdehit (MDA), TBA (Tiyobarbitürik asit) ile reaksiyona girerek, $532 \mathrm{~nm}$ 'de maksimum absorbans veren renkli bir kompleks oluşturmaktadır. MDA -TBA (TBARS) kompleksinin 532nm'deki ekstrinksiyon katsayısından $(1.56 \times 105 \mathrm{~cm}-1 . \mathrm{m}-1)$ yaralanarak $\mathrm{nmol} / \mathrm{ml}$ cinsinden MDA değeri bulundu. Sonuçlar ıslak doku başına nanomol olarak verildi.

\section{Katalaz enzim aktivitesinin ölçümü}

Katalaz (CAT) (CAT; E.C. 1.11.1.6) enzim aktivitesinin ölçümü Aebi'nin yöntemine göre çalışıldı (23). Hidrojen peroksit (H2O2) maksimum absorbansı 240 nm'de verir. H2O2'in katalaz tarafından su ve oksijene parçalanması esasına dayanır ve bu da kendini UV spektrofotometrede absorbans azalması şeklinde göstermektedir. Absorbanstaki bu azalma katalaz enziminin aktivitesi ile doğru orantılıdır. Numune ilavesi ile absorbans azalması her 15 sn'de bir defa olmak üzere 5 dakika süre ile okundu. Hesaplamada 1 dakikalık lineer absorbans azalmasının değerleri esas alındı.

\section{GSH-PX Aktivitesi Ölçümü}

GSH-Px (glutatyon peroksidaz) aktivitesi, spektrofotometrik yöntem ile ölçülmüştür. Yöntem, kümen hidroperoksit varlığında GSH-Px'in glutatyonun oksidasyonunu katalizlemesi sonucunda okside olan glutatyonun tekrar redükte forma dönüşmesi için harcanan NADPH'ın absorbansının 340 nm'de spektrofotometrik olarak ölçülmesi prensibine dayanır (24). Over, tuba uterina ve uterus dokularına ait GSH-Px aktivite değerleri, U/mg protein cinsinden ifade edildi.

\section{DNA Fragmantasyon Tayini}

EDTA’lı tüplere alınan kan örnekleri Apopitotik DNA Ladder kiti kullanılarak çalışıldı. Daha sonra elde edilen DNA örnekleri \%1'lik etidyum bromidli agaroz jelde 90V elektrik akımı ile yürütüldü. Bant paternleri UV translimünatör altında değerlendirildi.

\section{Histokimyasal Analizler}

Doku örnekleri \%10'luk nötral formaldehit solüsyonunda tespit edildi. Dokulara rutin takip prosedürü uygulandı. Parafin bloklara gömülen dokular 3-5 mikrometre kalınlığında kesilerek hematoksilen eozinle boyandı. Elde edilen preparatlar ışık mikroskobunda değerlendirilerek fotoğraflandı.

Kontrol ve deney gruplarına ait üreme sistemi organlarının kesitlerinde incelenen yapısal değişiklikler Refaiy ve arkadaşlarının yapmış oldukları skorlamaya göre değerlendirildi (25).

\section{İmmünohistokimyasal Analizler}

Parafin bloklara gömülen dokular 3-5 mikrometre kalınlığında kesilerek lizinli lamlara alndı. Elde edilen preparatlar Rabbit Anti-CD171/NCAM L-1 (BiOSS Cat: bs1996R USA), Rabbit Anti-Metallothionein-3 (GenetexCat: GTX60188 USA) ve E-cadherin/CDH1 (Thermo Cat: PA5-29252 Taiwan) antikorları kullanılarak boyandı. Daha sonra ışık mikroslobu altında semi-kantitatif değerlendirme yapıldı.

\section{İstatistiksel Analiz}

Yapılan deneylerden elde edilen verileri değerlendimede SPSS 17.0 istatistik programı kullanıldı. Ölçüm değerleri homojen dağılım göstermediği için non-parametrik testlerle çalışıldı. Gruplar arası farkın anlamlıığını değerlendirmede Kruskal-Wallis Varyans analiz testi kullanıldı. Anlamlı bulunan varyans analiz sonuçları Mann-Whitney $U$ ile sorgulandı. Anlamlılık sınırı p $<0.05$ olarak kabul edildi.

\section{Bulgular}

\section{Biyokimyasal Bulgular}

Kadmiyum verilen grupta MDA düzeylerinin kontrol grubuna göre istatiksel olarak anlamlı bir şekilde artış gösterdiği gözlenmiştir $(p<0,001)$. Ancak Melatonin ve selenyum uygulanan gruplarda da MDA düzeylerinde bir artış olduğu saptandı. Yine $\mathrm{Cd}+\mathrm{Mel}, \mathrm{Cd}+\mathrm{se}$ ve $\mathrm{Cd}+\mathrm{Mel}+\mathrm{Se}$ gruplarında da MDA düzeylerinde artış tespit edildi $(p<0,001)$. Bu sonuçlar, Melatonin ve selenyumun lipid peroksidasyonunu azaltmadığını göstermektedir (Şekil 1).

CAT enzimi bulguları ışığında, kontrol grubuna kıyasla 
tüm deney gruplarında katalaz enzim aktivitesinde düşüş gözlenmiştir. Cd verilen gruba kıyasla $\mathrm{Cd}+\mathrm{Mel}+\mathrm{Se}$ grubu haricindeki tüm deney gruplarında CAT enzim aktivite değerlerinde artış görülmüştür ( $p<0,001)$ (Şekil 2).

GSPx değerleri kadmiyum grubunda kontrol grubuna kıyasla düşmüştür. Diğer tüm deney gruplarında ise GSPx enzim aktivitesinde artış görülmüştür $(p<0,001)$. Melatonin ve selenyumu tek başına verdiğimiz gruplarda GSPx seviyesi kadmiyuma kıyasla daha fazla artmıştır. Ancak $\mathrm{Cd}+$ Melatonin ve Cd-selenyum verilen gruplarda sadece kadmiyum verilen gruba kıyasla bir GSPx değerlerinde düşüş gözlenmektedir. Bu düşme $\mathrm{Cd}$-selenyum grubunda

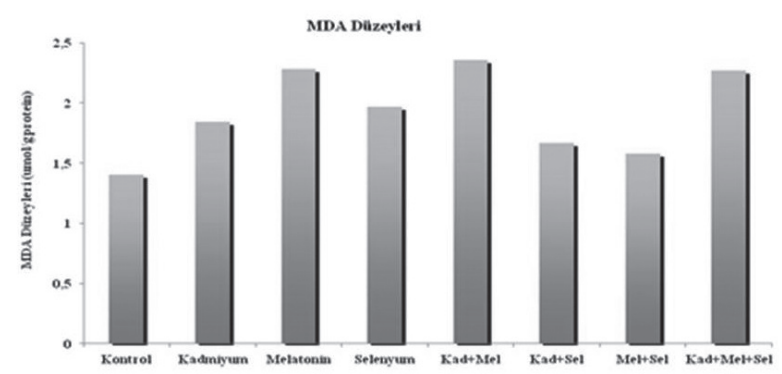

Şekil 1: Gruplara göre MDA düzeyleri

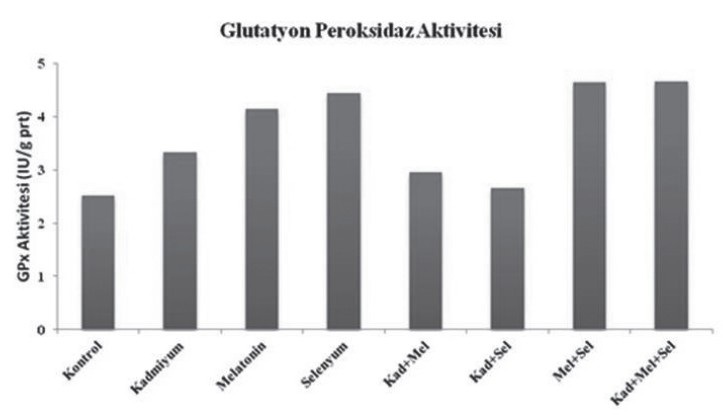

Şekil 3: Gruplara göre GSPx aktivitesi daha belirgindir. Ancak cd-Mel-se verilen grupta Cd grubuna göre enzim değeri artış göstermiştir (Şekil 3).

\section{DNA Fragmentasyon Bulguları}

Apopitotik DNA izolasyon bulgularımıza göre; kontrol grubunda DNA hücre hasarı görülmemektedir. Ancak kadmiyum verilen dişi sıçanların kan örneklerinden elde edilen sonuçlar ve görüntüler apopitotik hücre hasarı olduğunu göstermektedir. Melatonin, selenyum, kadmiyumMelatonin, kadmiyum-selenyum, Melatonin-selenyum ve kadmiyum-Melatonin-selenyum verilen gruplarda ise apopitotik DNA hücre hasarı görülmemektedir (Şekil 4).

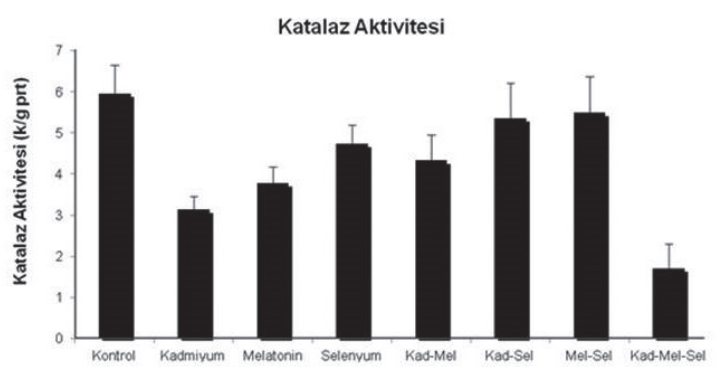

Şekil 2: Gruplara göre Katalaz aktivitesi

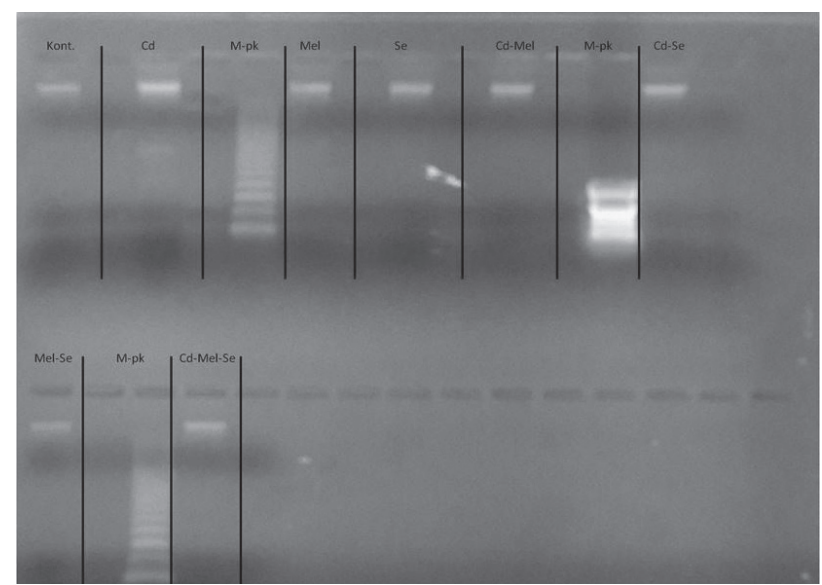

Şekil 4:

DNA elektroforezde yürütülmesi sonucu oluşan görüntü. Sadece kadmiyum grubunda apopitotik DNA hücre hasarı görülmektedir. Kont: Kontrol, Cd: Kadmiyum, M-pk: Marker pozitif kontrol, Mel: Melatonin, Se: Selenyum. 


\section{Histolojik Bulgular}

Kontrol grubu dişi sıçanlarının üreme sistemi organlarına ait kesitlerinin histolojik incelenmesinde, bu organlara ait normal histolojik yapılar dışında herhangi bir bulguya rastlanmadı (Şekil 5).
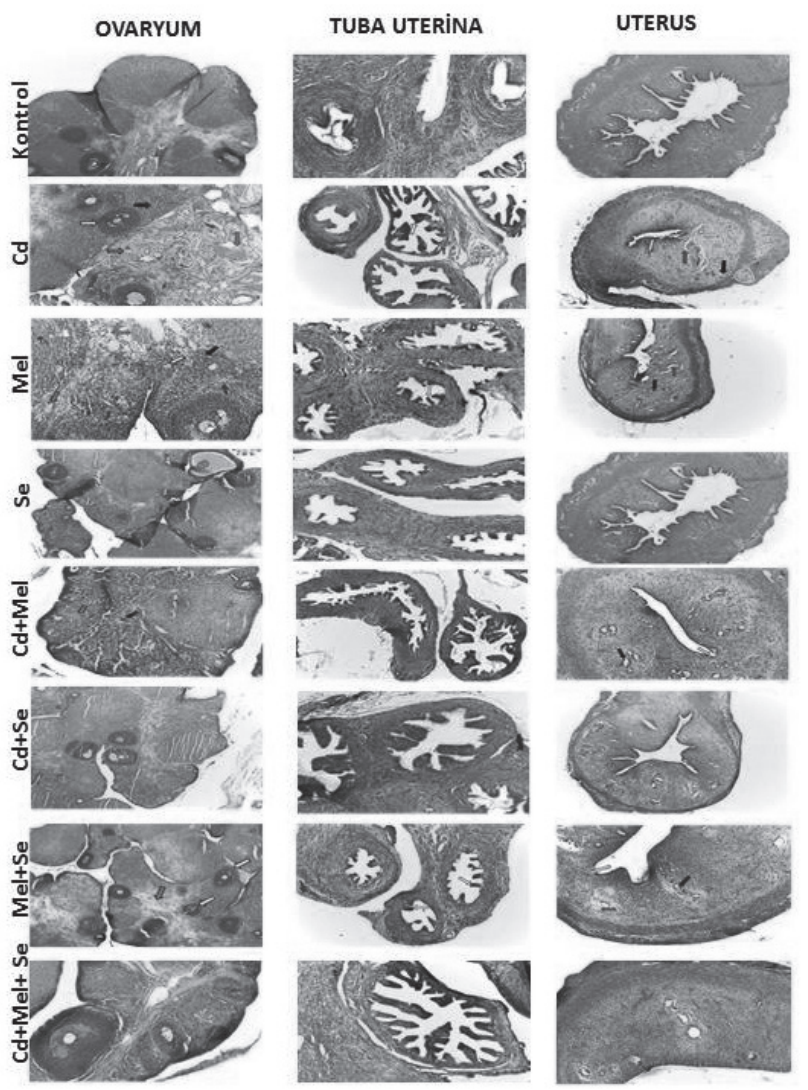

Şekil 5:

Kontrol; Kadmiyum; Melatonin; Selenyum; Kadmiyum + Melatonin; Kadmiyum + Selenyum; Melatonin + Selenyum; Kadmiyum + Melatonin + Selenyum gruplarına ait dişi rat iç genital sistem organları. Kontrol grubu iç genital sistem organlarında normal histolojik görüntü gözlemlenirken, tekli tedavi gruplarından Melatonin grubunda ve özellikle kadmiyum grubunda daha belirgin olmak üzere histopatolojik görüntülere rastlanmaktadır. Çoklu tedavi gruplarında ise Selenyumun belirgin histopatolojik düzelme sağladığı gözlenmektedir. Ovaryum; hemorajik alanlar mavi ok, mononükleer hücre infiltrasyonu siyah ok, bağ dokusu artışı yeşil ok, foliküler dejenerasyon sarı ok. Tuba uterina; epitelyal dejenerasyon sarı ok. Uterus; epitelyal dejenerasyon sarı ok, bağ dokusu dejenerasyonu kırmızı ok, endometrial bez dejenerasyonu siyah ok.

(H-E; x40, x100, x400)
Kadmiyum grubuna ait dişi üreme sistemi over kesitleri incelendiğinde kontrol grubuna göre mononükleer hücre infiltrasyonunda (MHi), foliküler dejenerasyon, hemorajik alanlar ve bağ dokusunda artış gözlendi $(p<0,05)$ (Şekil 5). Tuba uterina preparatları incelendiğinde tubüllerde dejenerasyon, tuba uterina epitelinde dejenerasyon ve genel olarak yapısal bir bozulma görüldü (Şekil 5). Uterus dokusu incelendiğinde ise endometriyum epitelinde dejenerasyon, bağ dokusunda dilate alanlar ve endometrial bezlerde dejenerasyon saptandı (Şekil 5).

Melatonin grubundaki dişi sıçanların over organına ait kesitleri incelediğimizde ise kadmiyum grubundakine benzer patolojik bulgular gözlendi (Şekil 5). Melatonin grubuna ait uterus ve tuba uterina organlarında ise kadmiyum grubundakine kıyasla biraz daha az olmakla birlikte yine benzer histopatolojik bulgular gözlendi (Şekil 5).

Selenyum grubuna ait over, tuba uterina ve uterus dokuları incelendiğinde kontrol grubuna benzer yapısal bulgular gözendi. Sadece düşük düzeyde ovaryum dokusunda foliküler dejenerasyon görüldü (Şekil 5).

Kadmiyum-Melatonin verdiğimiz dişi sıçanların ovaryum dokusunda Melatoninin herhangi bir koruyucu etkisi gözlenmedi. Hemorajik alanlarda ve bağ dokusu artışında bir miktar iyileşme saptandı ancak anlamlı değildi (Şekil 5). Tuba uterina dokusunda epitelde çok az düzelme gözlendi ancak anlamlı bir düzeyde değildi (Şekil 5). Uterus dokusunda endometriyal bezlerdeki dejenerasyonun neredeyse aynı şekilde devam ettiği gözlendi (Şekil 5).

Kadmiyum-selenyum verilen dişi sıçanların over dokularında selenyumun koruyucu etkisi gözlemlendi. Over dokusunda mononükleer hücre infltrasyonları (MHI), foliküler dejenerasyon, hemorajik alanlar ve bağ dokusu artışında anlamlı bir azalma saptandı $(p<0,05)$ (Şekil 5). Selenyumun koruyucu etkisi tuba uterina dokusunda da görüldü. Tuba uterina'nın epitelinde düzelme gözlemlendi (Şekil 5). Uterus dokusuna baktığımızda da over ve tuba uterina'daki düzelmenin bu dokuda da olduğu tespit edildi. Epitelde düzelme, bağ dokusundaki dilate alanlarda azalma ve endometriyal bezlerde düzelme saptandı (Şekil 5).

Melatonin-selenyum antioksidanlarının beraber verildiği dişi sıçanların over dokularında $\mathrm{MHI}$, foliküler dejenerasyon, hemorajik alanlar ve bağ dokusu artışının kadmiyum grubuna benzer şekilde devam ettiği gözlendi (Şekil 5). Bu grubun tuba uterina dokularında da epitel dejenerasyonu ve genel bir doku dejenerasyonu saptandı (Şekil 5). Kadmiyum verilen dişi sıçanın uterus dokusunda meyadana gelen epitel dejenerasyonu, bağ doku alanlarında dilatasyon 
ve endometriyal bezlerdeki dejenerasyon bulgularının Melatonin-selenyum grubunda da olduğu gözlemlendi (5).

Kadmiyum-Melatonin-selenyum verilen dişi sıçanların over dokusunda anlamlı bir düzelme gözlendi (Şekil 5). Aynı düzelme bu grupta tuba uterina ve uterus dokularında da saptandı (Şekil 5).

\section{İmmünohistokimyasal Bulgular}

Doku kesitlerinin immünohistokimyasal incelemesinde, kontrol grubuna ait over dokusunun granuloza hücreleri ile tuba uterina ve uterus dokusunun epitelinde E-cadherin boyamasının olmadığı gözlendi (Şekil 6). Kadmiyum verilen grupta ise E-cadherin sentezinin epitel hücrelerinde arttığ görüldü (Şekil 6). Kadmiyumun etkisini önlemek için verilen cd+Melatonin grubunda ise kadmiyum grubundakine benzer görütüler elde edildi (Şekil 6). Cd+selenyum verilen gruptaki E-cadherin görüntüleri ise kontrol grubundaki görüntülerle benzer olduğu belirlendi (Şekil 6). Melatonin+selenyum verilen grupta ise E-cadherin sentezinin $\mathrm{Cd}$ ve $\mathrm{Cd}+$ Melatonin gruplarına benzer şekilde olduğı gözlendi (Şekil 6). Cd+Melatonin+selenyum grubu incelendiğinde E-cadherin sentezinin kadmiyum grubuna göre biraz daha azaldığı tespit edildi (Şekil 6).
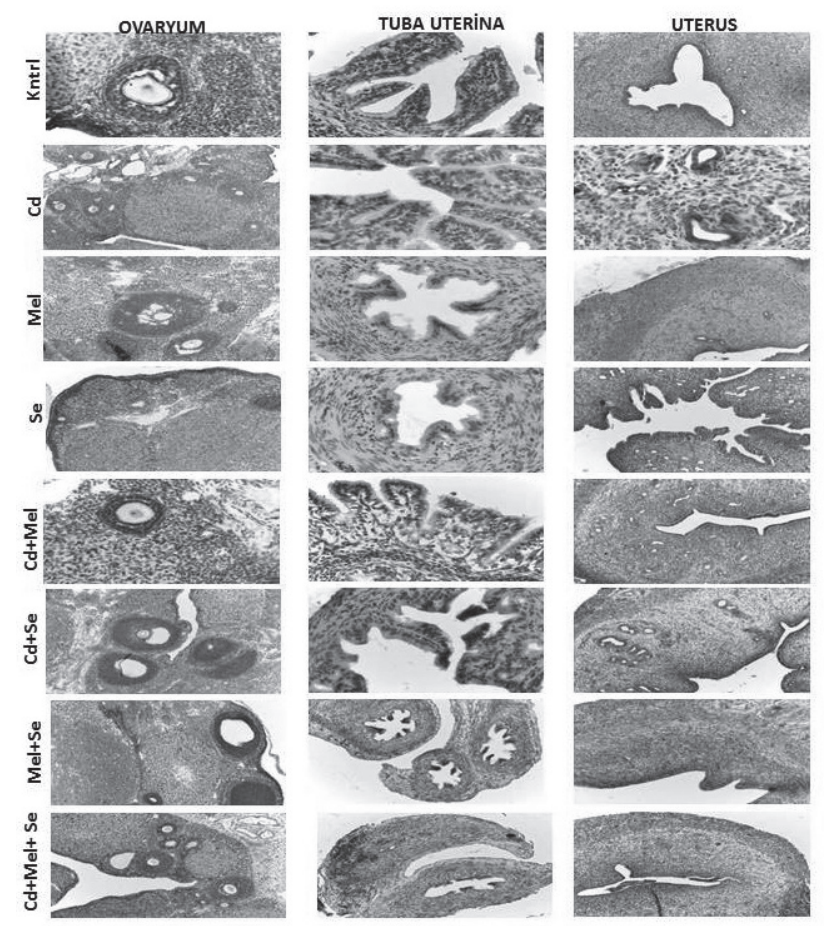

Kontrol grubunun ovaryum dokusu incelendiğinde, granuloza hücrelerinde NCAM ile boyanmadığı gözlendi (Şekil 7). Aynı şekilde tuba uterina'nın epiteli ve uterusun epiteli ile endometriyal bezlerinde NCAM ile boyanmanın olmadığı görüldü. Toksik ajan olarak kadmiyumun verildiği grupta ise granuloza hücrelerinde ve özellikle çevresindeki bağ dokusu yapısındaki teka interna ve externa yapılarında NCAM sentezinin arttığı saptandı (28). Kadmiyum grubunda uterusun endometriyal bezlerinde ve endometriyum tabakasında NCAM sentezinin arttığı tespit edildi (Şekil 7). Cd+Melatonin verilen grupta ise sadece kadmiyum verilen gruptaki görüntülere kıyasla NCAM sentezinin biraz azaldığı saptandı (Şekil 7). Cd+selenyum verilen grubumuzun ise NCAM sentezinin dokularda oldukça azaldığı ve kontrol grubuna yakın görüntüler gözlendi (Şekil 7). Melatonin+selenyum verilen grupta ise overin granuloza hücreleri ve teka tabakalarında, tuba uterina epitelinde ve uterusun endometriyum tabakasıyla endometrial bezlerinde herhangi bir NCAM sentezi artışı olmadığı gözlendi (Şekil 7). $\mathrm{Cd}+$ Melatonin + selenyum verilen grupta da selenyum, $\mathrm{Cd}+$ selenyum ve Melatonin + selenyum grubundaki görüntülerde olduğu gibi NCAM sentezinin normal olduğu saptandı (Şekil 7).

Şekil 6:

Kontrol; Kadmiyum; Melatonin; Selenyum; Kadmiyum + Melatonin; Kadmiyum + Selenyum; Melatonin + Selenyum; Kadmiyum + Melatonin + Selenyum gruplarına ait dişi rat iç genital sistem organları. Kontrol grubuna ait iç genital sistem organ epitelinde boyanma gözlenmezken, kadmiyum grubunda boyanma yoğunluğunun arttığı gözlenmektedir. Kadmiyumun selenyum ile kombine edildiği ikili ve üçlü tedavilerde boyanma yoğunluğunun azaldığı gözlenmektedir.

(E-Cadherin immüm boyama; x40, x100, x400) 
Kontrol grubuna ait dişi sıçanların genital sistem organlarında metallotiyonin-3 (MT-3) proteini birikiminin olmadığı gözlemlendi (Şekil 8). Kadmiyum verilen grupta ise ovaryumun granuloza hücrelerinde ve etrafını çevreleyen teka interna ve teka eksterna tabakalarında yoğun biçimde MT-3 boyanması gözlendi (Şekil 8). Tuba uterina'nın epiteli ve bağ dokusunda da MT-3 boyanmaları saptandı (Şekil 8). Uterus'un epitelinde MT-3 boyanması gözlendi ancak endometriyum tabakası ve endometriyal bezlerdeki MT-3 boyanması daha yoğundu (Şekil 8). Melatonin verilen grubun over dokusunun granuloza hücrelerinde boyanma görülmezken teka interna ve eksterna tabakalarında hafif MT-3 boyanmaları gözlendi (Şekil 8). Tuba uterina'da MT-3 boyanması gözlenmedi (Şekil 8). Ancak uterusun endometriyal bezlerinde MT-3 boyanmaları saptandı (Şekil 8). Selenyum verilen grubun over ve tuba dokularında MT-3 proteini birikimine bağlı bir boyanmaya rastlanmadı (Şekil 8). Ancak uterus'un endometriyal bezlerinde hafif MT-3 boyanmaları gözlendi (Şekil 8). Cd+Melatonin verilen
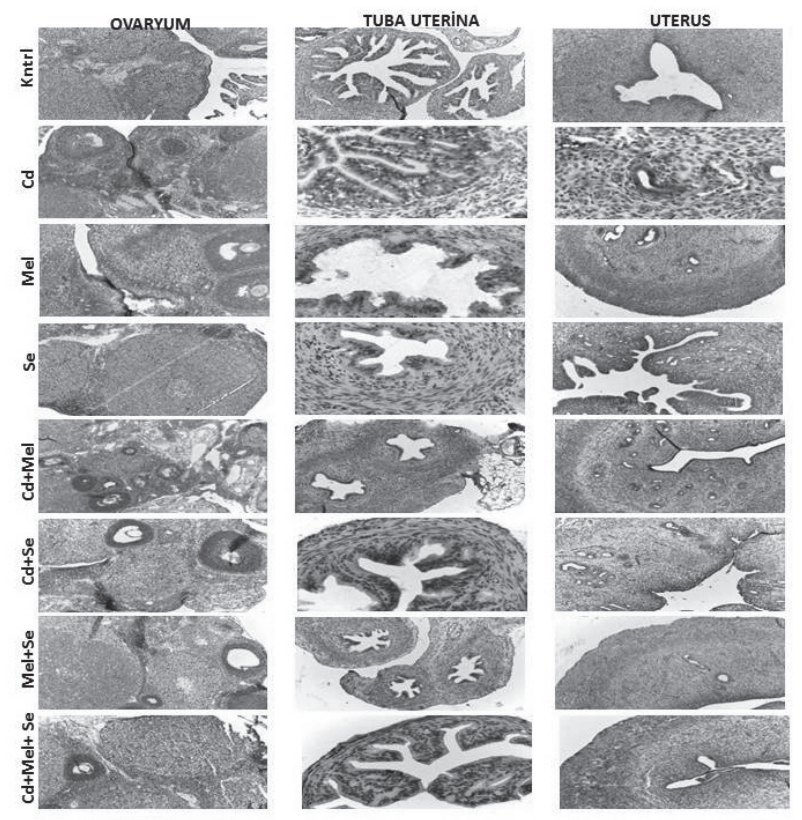

\section{Şekil 7:}

Kontrol; Kadmiyum; Melatonin; Selenyum; Kadmiyum + Melatonin; Kadmiyum + Selenyum; Melatonin + Selenyum; Kadmiyum + Melatonin + Selenyum gruplarına ait dişi rat iç genital sistem organları. Kontrol grubuna ait iç genital sistem organlarında boyanma gözlenmezken, kadmiyum grubunda epitelyal ve stromal dokuda boyanma gözlendi. Melatonin + selenyum grubunda boyanma gözlenmezken, Kadmiyum+selenyum grubunda belirgin olmak üzere ikili ve üçlü tedavi gruplarında boyanma yoğunluğunun azaldığı gözlemlendi. (NCAM immüm boyama; x40, x100, x400) grupta over dokusunda yoğun MT-3 boyanmaları gözlendi. $\mathrm{Bu}$ boyanmalar özellikle foliküllerin etrafını çevreleyen teka interna ve eksterna tabakalarında yoğunlaşmıştı (Şekil 8). Tuba uterina dokusunun epitelinde boyanma gözlenmezken, lamina propriya ve tunika advenitisya tabakalarında MT-3 boyanmaları saptandı (Şekil 8).

Uterus dokusunda ise epitelde hafif MT-3 boyanmaları gözlenirken, endometriyal bezlerde yoğun MT-3 boyanmaları tespit edildi (Şekil 8). Cd+selenyum grubunun over, tuba uterina ve uterus dokularında MT-3 boyanmaları gözlenmedi (Şekil 8). Melatonin+selenyum verilen grubun over dokusunda MT-3 boyanması gözlenmezken, tuba ve uterus dokularında çok az MT-3 boyanmaları saptandı (Şekil 8). Cd+Melatonin+selenyum verilen grubun over dokusundaki foliküllerin etrafını çevreleyen teka interna ve eksterna tabakalarında hafif boyanmalar gözlenirken tuba uterina'da MT-3 boyanmasına rastlanmadı (Şekil 8). Uterus dokusunda ise MT-3 boyanması gözlenmedi (Şekil 8).
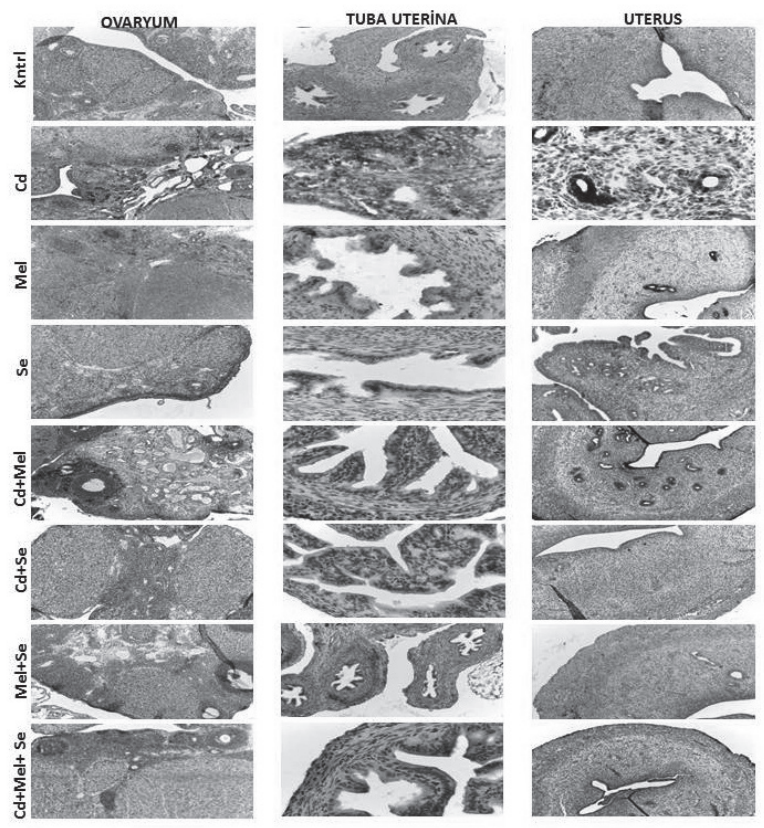

\section{Şekil 8:}

Kontrol; Kadmiyum; Melatonin; Selenyum; Kadmiyum + Melatonin; Kadmiyum + Selenyum; Melatonin + Selenyum; Kadmiyum + Melatonin + Selenyum gruplarına ait dişi rat iç genital sistem organları. Kontrol grubuna ait iç genital sistem organlarında boyanma gözlenmezken, kadmiyum grubunda epitelyal ve stromal dokuda yoğun boyanma gözlendi. Melatonin grubunda hafif boyanma gözlenirken, selenyum grubunda çok hafif boyanma gözlendi. İkili ve üçlü tedavi gruplarında hafif düzey boyanmalar devam ederken sadece kadmiyum+selenyum grubunda boyanma gözlenmedi.(MT-3 immüm boyama; x40, $\mathrm{x} 100, \mathrm{x} 400)$ 


\section{Tartışma}

Ağır bir metal olan kadmiyum major çevresel toksik ajanlardan biridir. Doğada kadmiyum sülfat, kadmiyum oksit ve kadmiyum klorür şeklinde ve genelde çinko, bakır ve kurşun madenleriyle birlikte ince partiküller şeklinde bulunur. Fizyolojik olarak non-esansiyel bir metaldir. İnsan ekolojisi açısından kadmiyum havadan solunumla alınır. Besinlerle, sigara ve hava yolu ile günde yaklaşık olarak 18-200 $\mu \mathrm{g} \mathrm{Cd}$ alındığı tespit edilmiştir. Solunan havada alınan miktar $0,1-0,5 \mu \mathrm{g} \mathrm{Cd} / \mathrm{m}^{3}$ düzeyinde bulunması durumunda akciğerler için önemli tehlike arz eder. Günde 20 adet sigara içen bir insan 2-4 $\mu \mathrm{g}$ Cd almaktadır. Sigara içen bireyler nikotin, kadmiyum, kurşun ve civa gibi bir çok kimyasal bileşiğe maruz kalmaktadırlar (26).

Kadmiyumun ana kaynağı yiyeceklerdir. Buna ek olarak diğer en önemli vücuda alınma kaynaklarından biri de sigaradır. Cd vücuda gastrointestinal, respiratuar ve dermal yol ile alınır (27). Kadmiyum, proteinlerde tercihen sülfidril gruplarına ve DNA fosfatlarından çok DNA bazlarına bağlanır. Cd-DNA bağlanma aracılığı ile sülfidril ihtiva eden antiosidan enzimlerin inhibisyonuna ve reaktif oksijen çeşitlerinin indüklenmesine neden olur. Ayrıca kadmiyumun indirekt olarak antioksidan düzeyini azalttığı ve intrasellüler $\mathrm{H}_{2} \mathrm{O}_{2}$ artışı yaptığı gösterilmiştir. Serbest radikaller DNA çapraz bağı yapmakta ve lipid peroksidasyonunu tetiklemektedir. Kadmiyum aynı zamanda transkripsiyon faktörlerinden Zn parmak motifi içinde Zn'nin yerini alır. Çünkü kadmiyum fizyolojik koşullar altında redoks aktif değildir. (26).

Kadmiyumun etkilerini sıralayacak olursak; membran yapı/ fonksiyon değişimi, antioksidan enzimlere karışma, tiol proteinlerde değişim, enerji metabolizmasında inhibisyon, DNA yapısında değişim, stress genlerinin ekspresyonunun indüklenmesi ve bazı enzimatik aktivite etkilerinde önemli rol oynar (26).

Çalışmamızda kadmiyumun DNA'da fragmantasyon oluşturup oluşturmadığını inceledik. DNA ladder Kit kullanarak yaptığımız testler neticesinde kadmiyum grubunda DNA fragmantasyonu meydana getirdiğini gördük. Daha once yapılan çalışmalarda kadmiyumun DNA yapısında değişim meydana getirdiği bildirilmiştir (26). Biz de kadmiyumun DNA kırıklarına sebep olduğunu buna bağlı olarak da apopitozu artırdığını düşünmekteyiz.

Kadmiyum'un insanda karsinojen etki yaptığı 1976 yılında gösterilmiş ve 1993 yılında, IARC (International Agency for Cancer Research) tarafından Tip 1 karsinojen olarak sınıflandırılmıştır (28). Kadmiyumun böbrek, prostat, karaciğer ve pankreası içeren birçok organda kanserojenik etki gösterdiği bildirilmektedir. Ayrıca yapılan bir çalışmada kadmiyumun teratojenik olduğu ve doza bağlı barsak anomalisi ve oküler anomali gibi malformasyonlar oluşturduğu gözlenmiştir (26).

Endüstri alanında çalışan ve sigaranın bileşenlerinden olan kadmiyuma maruz kalan kadınlarda meme kanseri insidansının yüksek olduğu araştırılmıştır (27).

Kadmiyum insan vücudunda oldukça uzun süren bir yarılanma ömrüne sahiptir. Başta karaciğer ve böbrek olmak üzere bütün vücutta birikme eğilimi göstermektedir. Kadmiyumun hızlı komponenti vücutta 75-128 günlük yarılanma ömrüne sahipken, yavaş kompanenti 7,4-26 yıl gibi uzun bir yarılanma ömrüne sahiptir (27).

Yapılan bir çalışmada memeli testis ve ovaryumunda kadmiyum birikimi olduğu görülmüştür (26). Çalışmamızda kadmiyum verdiğimiz gruplarda ovaryum, tuba uterina ve uterus dokularımızda kadmiyum birikimi olduğunu belirledik. Vücudumuzun antioksidan savunma sistemi serbest radikallere ve ilgili ürünlerine dolaylı yoldan etki eden antioksidan enzimler ve doğrudan etki eden Melatonin gibi düşük ağırlıklı moleküllerden destek almaktadır (29). Vücutta, serbest radikaller (oksidan maddeler) ile antioksidan savunma sistemi arasında bir denge vardır ve bu dengenin oksidanların lehine bozulması durumuna, 'oksidatif stres' denir (30).

Selenyum (Se), bir çok enzimin yapısında bulunması nedeniyle canlı organizmalar için gerekli bir iz elementtir. Selenyum canlılarda düşük derişimlerde antioksidan role sahipken, yüksek derişimlerde ise toksik olduğu belirtilmiştir. Selenyum antioksidan savunmayla ilgili enzimlerde gerekli bir kofaktördür (30).

Kadmiyumun oksidatif stresi indüklediği, buna bağlı olarak GSPx ve CAT aktivitesini eş zamanlı düşürdüğü, metallotiyoninler ve MDA'yı ise arttırdığı tespit edilmiştir. Kadmiyumdan sonra mutasyonal değişiklikler artar ve buna bağlı olarak antioksidan enzimler olan GSPx ve CAT sentezi azalır (31).

Yaptığımız biyokimyasal analizler ve ortaya çıkan bulgular neticesinde kadmiyum verdiğimiz hayvanlarda oksidatif stress faktörlerinin artmasına bağlı olarak antioksidan enzimler olan GSPx ve CAT'ın sentezinin arttığını gördük. $\mathrm{Bu}$ artışın oluşan lipid peroksidatif hasarı kompanse edebilmek için antioksidan enzimlerin sentezinin atmasına bağlı olduğunu düşünmekteyiz. Kadmiyumun oluşturduğu bu toksik etkiden dokularımızı korumak için Melatonin ve 
selenyum verdik. Melatoninin kadmiyumun oluşturuduğu toksik etkileri korumada yeterli etkiyi göstermezken selenyum verdiğimiz ratlarda GSPx ve CAT enzim seviyelerinin düştüğünü biyokimyasal analizler sonucu tespit ettik. Buradan yola çıkarak kadmiyuma bağlı dişi genital sistem hasarında selenyumun koruyucu etkisinin daha fazla olduğunu düşünmekteyiz.

Çolakoğlu ve ark.'ının (2011) yaptığı bir çalışmada, normal şartlarda organizmada sentezlenen ve ağır metalleri bağlayıp detoksifikasyonunda önemli bir göreve sahip olan metallotiyoneinin ekzojen olarak uygulanmasının herhangi bir koruyucu ya da tedavi edici etkisinin olmadığı sonucuna varmışlardır. Bunun sebebinin ise dışarıdan verilen MT'nin dozunun yetersiz olduğunu veya in vivo olarak organizmanın sentezlediği MT'nin sentetik olarak uygulanandan daha güçlü bir terapötik etkiye sahip olduğu fikrini ortaya koymuşlardır (32).

İmmünohistokimyasal boyamalar neticesinde $\mathrm{Cd}$ verilen ratların ovaryum, tuba uterina ve uterus dokularında MT-3 birikiminin yoğun olduğunu gördük. Koruma amaçlı verdiğimiz antioksidan ajanlarımızdan Melatoninin herhangi bir etkisini görmezken, selenyum verdiğimiz gruplarda MT-3 birikiminin anlamlı bir şekilde azaldığını gözlemledik. $\mathrm{Cd}+\mathrm{Mel}+$ se verdiğimiz grupta da dokularda MT-3 birikiminin azaldığını saptadık. Ancak bu azalma cd+se verilen gruplarda daha fazlaydı.

Jia ve arkadaşları, ovaryum foliküllerinin granüloza hücrelerinde kadmiyumun hücre içi hasarı indüklediğini ve buna bağlı olarak DNA fragmantasyonuna neden olduğunu ve bu olayın hücreyi ölüme götürdüğünü bulmuşlardır (33). Biz de kadmiyum verdiğimiz sıçanlarda yaptığımız histopatolojik incelemeler sonucunda ovaryum dokusundaki foliküllerde dejenerasyon ve immünohistokimyasal incelemelerde de granuloza hücrelerinde hasar oluştuğunu tespit ettik.

Massanyı ve arkadaşları (1995), uzun süreli kadmiyuma maruz kalan over granuloza hücrelerinde morfolojik değişiklikler, sitoplazmalarında vakuoller, nadir olarak bozulmadan kalan golgi kompleksi ve sayısı artmış lizozomlar tespit etmişler. Bu veriler ışığında da granuloza hücrelerinin steroid sentezini etkilediğini saptamışlardır. Kadmiyumdan en fazla etkilenen dişi genital organın ovaryum daha sonrada uterus olduğunu bildirilmiştir. Kadmiyumun uterustaki mikrosirküler kan akımını bozduğu tespit edilmiştir. Kadmiyum maruziyetinde ovaryumun granuloza hücrelerinin ve uterusun endometriyum tabakasının dişi genital sistem organlarında en fazla etkilenen bölgeler olduğunu belirtmişlerdir $(9,10)$.
Genç hamsterlara yüksek doz kadmiyum uygulamasından sonra uterusta kanamalara neden olduğu gösterilmiştir. Ratlarda da doza ve yaşa bağlı olarak kadmiyumun toksitesinin ovaryum, uterus ve servikste benzer toksik etkiler gösterdiği bulunmuştur (34).

Sigara içen dişi bireylerin in vitro fertilizasyonunda foliküler sıvılarında kadmiyum oranının sigara içmeyenlere oranla daha yüksek olduğu rapor edilmiştir. Tekrarlayan düşük ve miyomlarda dişilerdeki idrar analizleri sonucu kadmiyum miktarının artmış olduğunu bulmuşlardır (34).

Çalışmamızda histokimyasal incelemeler neticesinde kadmiyum grubundaki ratların ovaryum dokularında hemorajik alanlar, bağ dokusu artışı, foliküler dejenerasyon ve mononükleer hücre infiltrasyonları gibi yapısal değişiklikler oluştuğunu gördük. Uterus dokusunda ise epitelde dejenerasyon, endometriyum tabakasında dilate alanlar ve endometriyal bezlerde dejenerasyon bulguları elde edildi. Yine kadmiyum verdiğimiz ratların tuba uterina epitelinde dejenerasyon ve genel olarakta bir hasar meydana getirdiğini gözlemledik. Histokimyasal ve immünohistokimyasal bulgularımız da biyokimyasal ve DNA fragmantasyon bulgularımızı destekler nitelikteydi.

Ovaryumda yaşla birlikte kadmiyum birikimi artar ve bu durum ovulasyonun ilerlemesinde hataya neden olmaktadır. Başka bir etkisinin de ovulasyonun hiç olmaması, tuba uterinanın silyalarının oositi tutamamasına veya iletememesine, oosit-kumulus ooforius kompleksinde ve bu kompleksten adezyon moleküllerinin ekspresyonunda defektlere neden olmaktadır. Oksidatif stress ve hücreler arası mekanizmada sorunlar ortaya çıkarmıştır. Foliküler arterlerin endoteline ve overin interstisyal stromasına hasar verir Kumulus hücrelerinin genişlemesinin baskılanması, oositlerin metafaz Il'ye ulaşmasında azalma, oositlerin fertilizasyonunda azalma ve oosit dejenerasyonunda artış olmuştur (35).

Yapılan son çalışmalarda kadmiyum ve diğer toksik metallerin, kaderinlerin $\mathrm{Ca}^{+2}$ tutunma bandlarında defektler meydana getirdiği bulunmuştur. Kadmiyum için hedef bölge kaderinlerin sinyal yolaklarından bir veya birden fazlasını bozarak etki ettiği düşünülmektedir. Kadmiyum ATP ve glutatyon seviyelerini değiştirerek E- cadherinlerin fonksiyonlarının bozulmasına neden olmaktadır. Bu durum özellikle kaderin $/ \beta$ katenin $\left(\mathrm{Ca}^{+2}\right.$ bandları) bozulmasına neden olarak gelişmektedir. Kadmiyumun kaderin/ $\beta$ katenin bağlantısını bozmasıyla kanser oluşumları meydana gelmektedir (36).

Selenyumun ise hücre ve dokuları kadmiyumun zararlı 
etkisinden kurtardığı ya da koruduğu bildirilmiştir (34).

Kadmiyumun NCAM'ın hücre dışı domainleriyle etkileşime geçerek fonksiyonunu bozduğu ve hücre dışı bağlantılarına hasar verdiğini göstermişlerdir (36).

Yaptığımız immünohistokimyasal boyamalar neticesinde kadmiyum verdiğimiz ratların granuloza hücrelerinde, tuba uterine epitelinde ve uterus epitelinde E-cadherin sentezinin artığını gördük. Bu durum kadmiyumun $\mathrm{Ca}^{+2}$ bağımlı adezyon mokekülü E-cadherinin fonksiyonunu bozduğunu göstermektedir. Aynı şekilde diğer bir adezyon molekülümüz NCAM'ın sentezinin özellikle uterusta oldukça arttığını tespit ettik. Kadmiyumun adezyon molekülleri üstündeki bu zararlı etksinden korumak için verdiğimiz antioksidan ajanlardan Melatonin herhangi bir koruyucu etki göstermedi. Ancak Cd + selenyum, Cd + selenyum + Melatonin beraber verdiğimiz gruplarda E-cadherin ve NCAM sentez düzeylerinin azaldığını tespit ettik. Bu azalma $\mathrm{CD}+$ selenyum grubunda daha fazla idi.

Kadmiyumun zararlı etkilerinden koruma amaçlı verdiğimiz antioksidan ajanımız Melatoninden istediğimiz sonucu alamamızın dişi ratlardaki hormonal değişimlerin değişkenliğine bağlı olduğunu düşünmekteyiz. Hormonal etkileşimler oldukça hassas dengeler içinde devam eder. $\mathrm{Bu}$ nedenle çalışmamızda uzun süreli koruma amaçlı Melatonin kullanımı dokularımızı korumaktan ziyade hasar oluşturmaya başladığını gözlemledik. Buradan yola çıkarak kullanılan antioksidanların koruyucu etki göstermesinin doza, kulanılan süreye ve hormonal etkileșime (özellikler dişilerde) bağlı olarak değiştiğini söyleyebiliriz.

\section{Teşekkür}

$\mathrm{Bu}$ çalışma Süleyman Demirel Üniversitesi Bilimsel Araştırma Projeleri Koordinasyon Birimi tarafından desteklenmiștir (SDÜ-BAP, Proje No: 4310-D1-15).

\section{Kaynaklar}

1. Ceylan S, Sanlı Y, 1980. Çevre ve Besin Kirlenmesi. Gıda Bil. Teknol. Derg, 3 (1-2), 76-92.

2. Prozialeck W.C, Edwards, J.R., Woods, J.M., 2006. The Vascular Endothelium as a Target of Cadmium Toxicity. Life Sci 79 (16), 1493-1506.

3. Baş L, Demet Ö. 1992. Çevresel Toksikoloji Yönünden Bazı Ağır Metaller. Ekoloji, 5; 42-46.

4. Aydoğdu, N., Kanter, M., Erbas, H., Kaymak, K., 2007. Kadmiyuma Bağlı Karaciger Hasarında Taurin, Melatonin ve Asetilsisteinin Nitrik Oksit, Lipit Peroksidasyonu ve Bazı Antioksidanlar Üzerindeki Etkileri. Erciyes Tıp Dergisi
(Erciyes Medical Journal), 29 (2), 089-096.

5. Kolluru GK, Tamilarasan KP, Priya SG, Durgha NP, Chatterjee S. 2006. Cadmium induced endothelial dysfunction: Consequence of defective migratory pattern of endothelial cells in association with poor nitric oxide availability under cadmium challenge. Cell Biol Int. 30(5):427-438.

6. Wätjen W, Cox M, Biagioli M, Beyersmann D. 2002. Cadmium-induced apoptosis in C6 glioma cells: Mediation by caspase 9 activation. Biometals. 15:15-25.

7. Joseph P. 2009. Mechanisms of cadmium carcinogenesis. Toxicol Appl Pharmacol. 238: 272-279.

8. Siu ER, Mruk DD, Porto CS, Cheng CY. 2009. Cadmiuminduced testicular injury. Toxicol Appl Pharmacol. 238: 240249.

9. Massanyi P, Toman R, Najmık F. 1995. Concentrations of Cadmium in Ovary, Oviductus, Uterus, Testis and Tunica Albuginea of Testis in Cattle. J Environ Sci Health. 30: 1685-1692.

10. Massanyi P, Uhrin V, Toman R., Pivko J, Luka N, Forgacs ZS, Somosy Z, Fabi M, Danko J. 1995. Ultrastructural Changes of Ovaries in Rabbits Following Cadmium Administration. Acta Vet. Brno. 74: 29-35.

11. Paksy K, Rajczy K, Forgács Z, Lázár P, Bernard A, Gáti I, Kaáli GS. 1997. Effect of cadmium on morphology and steroidogenesis of cultured human ovarian granulosa cells. J Appl Toxicol. 17(5): 321-327.

12. Malik AB, Lo SK, Vascular endothelial adhesion molecules and tissue inflammation Pharmacol Rev 1996; 48: 213-29.

13. Jung $\mathrm{U}$, Ley $\mathrm{K}$, Mice lacking two or all three selectins demonstrate overlapping and distinct functions for each selectin. J Immunol 1999; 162: 6755-62.

14. Cabadak H. Hücre Siklusu ve Kanser. ADÜ Tıp Fak Der 2008; 9 (3): 51-61.

15. Miller L.L, Wang F, Palace V.P, and Hontela A. 2007. "Effects of Acute and Subchronic Exposure to Waterborne Selenite on the Physiological Stress Response and Oxidative Stress Indicators in Juvenile Rainbow trout", Aquatic Toxicology, 83, 263-271.

16. Fox, M. J., 1992. Selenium: Nutritional Implications and Prospects for Therapeutic Medicine. Meth Find Exp Clin Pharmacol, 14 (4), 275- 287.

17. Simonoff, M., Sergeant, C., Garnier, N., Moretto, P., Llabador, Y., Smonoff, G., Conri, C., 1992. Antioxidant Status (Selenium, Vitamins A and E) and Aging. Exs, 62, 368-97.

18. Çetin, E. 2005. "Melatonin ve Bağışıklık Sistemi", Erciyes Üniv Vet Fak Derg, 2(2), 119-123.

19. Erdem, M, Bostan, B, Güneş, T, Özkan, F, Şen, C, Özyurt, H, Köseoğlu, D.R, Erdoğan, H. 2010. "Protective effects of Melatonin on ischemia-reperfusion injury of 
skeletal muscle", Eklem Hastalıkları ve Cerrahisi, 21(3), 166-171.

20. Stajn A, Zikic R.V, Ognjanovic B, Saicic Z.S, Pavlovic S.Z, Kostic M.M, Petrovic V.M. Effect of Cadmium and Selenium on the Antioxidant Defense System in Rat Kidneys. Comp. Biochem. Physiol. 1997 Vol. 117C, No. 2 , pp. 167-172.

21. Moğulkoç R, Kasım Baltacı A. 2002. Hipertiroidi oluşturulan ratlarda intraperitoneal Melatonin uygulamasının tiroid hormonları ve testosteron salınmasına etkisi. Genel Tip Derg. 12(4):129-132.

22. Drapper HH, Hadley M. 1990. Melondialdehyde Determination as Index of Lipid Peroxidation. Methods Enzymol. 186: 421-431.

23. Aebi H. 1974. Catalase In: Bergmeyer U, ed. Methods of enzymatic analysis. New York and London Academic Press. pp.673-677.

24. Tapiero, H., Townsend, D.M, Tew, K.D., 2003. The Antioxidant Role of Selenium and Seleno-Compound. Biomedicine \& Pharmacotheraphy, 57, 134-144.

25. Refaiy A, Muhammad E, ElGanainy E. 2011. Semiquantitative Smoothelin Expression in Detection of Muscle İnvasion in Transurethral Resection and Cystectomy Specimen in Cases of Urinary Bladder Carcinoma. African Journal of Urology, Vol. 17, No. 1, 6-10.

26. Boğa A. 2007. Ağır Metallerin Özellikleri ve Etki Yolları. 16:218.

27. Olszowski T, Barana-Bosiacka I, Gutowska I, Chlubek D. 2012. Pro-inflammatory properties of cadmium. Acta ABP Biochimica Polonica Vol. 59, No 4. 475-482.

28. Siu R. Erica, Mruk D. Dolores, Porto S. Catarina, Cheng C. Yan. 2009. Cadmium-induced testicular injury. Toxicology and Applied Pharmacology. 238; 240-249.

29. Tran D, Moody A.J, Fisher A.S., Foulkes M.E., and Jhs, A.N. 2007. Protective Effects of Selenium on MercuryInduced DNA Damage in Mussel Haemocytes. Aquatic Toxicology. 84: 11-18.

30. Douillet C, Bost M, Accominotti M, Borson-Chazot F, Ciavatti M. 1998. Effects of selenium and vitamin $E$ supplements on tissue lipids, peroxides, and fatty acid distribution in experimental diabetes. Lipids. 33(4): 393-399. 31. Erdem, M, Bostan, B, Güneş, T, Özkan, F, Şen, C, Özyurt, H, Köseoğlu, D.R, Erdoğan, H. 2010. "Protective effects of Melatonin on ischemia-reperfusion injury of skeletal muscle", Eklem Hastalıkları ve Cerrahisi, 21(3), 166-171.

32. Çolakoğlu N, Kükner A, Ozan E, Kara H, Koyutürk L, Kuloğlu T. 2011. Sıçan Testis Dokusunda Kadmiyum Klorür'ün Oluşturduğu Yapısak Değişiklikler ve Bu Değişiklikler Üzerine Metallothionein'in Etkileri: Elektron Mikroskobik Çalışma. F.Ü. Sağ. Bil. Tıp Derg. 25(1): 05-09. 33. Jia Y, Lin J, Mi y, Zhang C. 2011. Quercetin attenuates cadmium-induced oxidative damage and apoptosis in granulosa cells from chicken ovarian follicles. Reproductive Toxicology, 31 477-485.

34. Ekincioğlu Z, Demir G, Güneş Dağ D, Pekmez H, Acer N, Özercan M. Reşat. 2008. Sigara Dumanının Uterusa Etkileri: Histopatolojik Bir Çalışma. Sağlık Bilimleri Dergisi 17 (2) 69-76.

35. Thompson J, Bannigan J. 2008. Cadmium: Toxic effects on the reproductive system and embryo. Reproductive Toxicology 25, 304-315.

36. Goyer, R.A, Clarkson, W.T., 2001. Toxic Effects of Metals. Edited by: Klaassen, C.D. Casarett and Doull's Toxicology, The Basic Science of Poisons, 6th ed, McGrawHill, USA, 811-827. 